\title{
Influence of Lithium Ions on the Ion-coordinating Ruthenium Sensitizers for Nanocrystalline Dye-sensitized Solar Cells ${ }^{\dagger}$
}

\author{
Nara Cho, Chi-Woo Lee, Dae Won Cho, Sang Ook Kang, Jaejung Ko, " and Mohammad K. Nazeeruddin* \\ Department of Advanced Material Chemistry, Korea University, Jochiwon, Chungnam 339-700, Korea*E-mail:jko@korea.ac.kr \\ * Laboratory for Photonics and Interfaces, Swiss Federal Institute of Technology, CH 1015, Lausanne, Switzerland \\ Received January 5, 2011, Accepted May 30, 2011
}

\begin{abstract}
Ion-coordinating ruthenium complexes $[\text { cis-Ru(dcbpy)(L)(NCS })_{2}$, where dcbpy is 4,4'-dicarboxylic acid-2,2'bipyridine and $\mathbf{L}$ is 1,4,7,10-tetraoxa-13-azacyclopentadecane, JK-121, or bis(2-(2-methoxy-ethoxy)ethyl) amine, JK-122] have been synthesized and characterized using ${ }^{1} \mathrm{H}$ NMR, Fourier transform IR, UV/vis spectroscopy, and cyclic voltammetry. The effect of $\mathrm{Li}^{+}$in the electrolyte on the photovoltaic performance was investigated. With the stepwise addition of $\mathrm{Li}^{+}$to a liquid electrolyte, the device shows significant increase in the photo-current density, but a small decrease in the open circuit voltage. The solar cell with a hole conductor, the addition of $\mathrm{Li}^{+}$resulted in a 30\% improvement in efficiency. The $\mathbf{J K - 1 2 1}$ sensitized cells in the liquid and solid-state electrolyte give power conversion efficiencies of $6.95 \%$ and $2.59 \%$, respectively, under the simulated sunlight.
\end{abstract}

Key Words : Dye, Dye-sensitized solar cell, Ruthenium sensitizer, Lithium cation coordination

\section{Introduction}

Environmental issues such as fossil fuel shortage and global warming have led to a greater attention on clean renewable energy during the last years. For this purpose, dye-sensitized solar cells (DSSCs) have received a great deal of attention as low-cost devices for conventional $p-n$ junction solar cell ${ }^{1}$. Some polypyridyl ruthenium sensitizers ${ }^{2}$ have achieved power conversion efficiencies over $11 \%$ in standard air mass 1.5 sunlight. However, the efficiency of DSSCs needs to be more improved in order to become competitive with silicon-based photovoltaic cells. One of the possible approaches to increase the efficiency lies in diminishing the charge recombination by interface engineering of a dye-absorbed $\mathrm{TiO}_{2}$, which is the main loss mechanism in competition with charge transport processes. The efficient operation of the DSSC device relies on the minimization of the possible recombination pathways occurring at the $\mathrm{TiO}_{2} /$ dye/electrolyte interface. The strategy to reduce such losses involves the coating of inorganic barrier layers ${ }^{3}$, selfassembled molecular dipoles ${ }^{4}$, saccharides ${ }^{5}$, metal-assembling dendrimers $^{6}$, the introduction of long alkyl chains onto the dyes $^{7}$, and the addition of co-grafting additives to the $\mathrm{TiO}_{2}$ surface $^{8}$. Recently, an alternative approach has addressed where the addition of $\mathrm{Li}^{+}$to photoanode functions as an active device layer altering the dipole field at the interfacial region' ${ }^{9}$ Several groups have investigated novel ruthenium sensitizers and ion-solvating supramolecular arylamines by tethering the triethylene oxide methyl ether (TEOME) to introduce ion coordinating properties to the compounds ${ }^{10-16}$. Lithium ion tethered by the TEOME group has been

This paper is dedicated to Professor Eun Lee on the occasion of his honourable retirement. demonstrated to retard the recombination by screening the electrons in the $\mathrm{TiO}_{2}$ from $\mathrm{I}_{3}^{-}$. Such approach has been found to be very effective in controlling the interfacial recombination processes. However, the weak coordinating power of such a flexible TEOME unit to the lithium ion prevented the exact role of $\mathrm{Li}^{+}$to the retardation of interfacial charge recombination.

In this paper we extend our studies to another alternative solubilization strategy based upon the introduction of 1,4,7,10-tetraoxa-13-azacyclopentadecane (L1) ${ }^{17}$ and bis(2(2-methoxyethoxy)ethyl)-amine $(\mathbf{L} 2)^{18}$ side groups to the 4.4'-position of a 2,2'-bypyridine ligand in order to coordinate the lithium ion strongly, as illustrated in Fig. 1 and control charge transfer at the dye sensitized nanocrystalline $\mathrm{TiO}_{2}$ /organic semiconductor heterojunction.

\section{Experimental Section}

General Methods. All reactions were carried out under an argon atmosphere. Solvents were distilled from appropriate reagents. All reagents were purchased from Sigma-Aldrich, TCI, Acros Organics and Samchun chemicals. 4,4'-Bis(4(1,4,7,10-tetraoxa-13-azacyclopentadecan-13-yl)styryl)-2,2'bipyridine $(\mathbf{L 1})^{17}$ was synthesized using a modified procedure of previous references. ${ }^{1} \mathrm{H}$ NMR and ${ }^{13} \mathrm{C}$ NMR spectra were recorded on a Varian Mercury 300 spectrometer. Elemental analyses were performed with a Carlo Elba Instruments CHNS-O EA 1108 analyzer. Mass spectra were recorded on a JEOL JMS-SX102A instrument. The absorption and photoluminescence spectra were recorded on a Perkin-Elmer Lambda 2S UV-visible spectrometer and a Perkin LS fluorescence spectrometer, respectively. Cyclic voltamogram was carried out with a BAS 100B (Bioanalytical System, Inc.). A three electrode system was used and consisted of a 


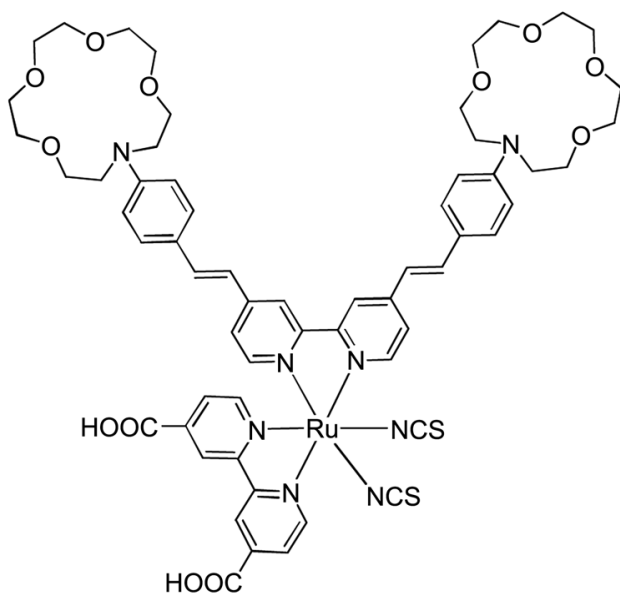

JK-121

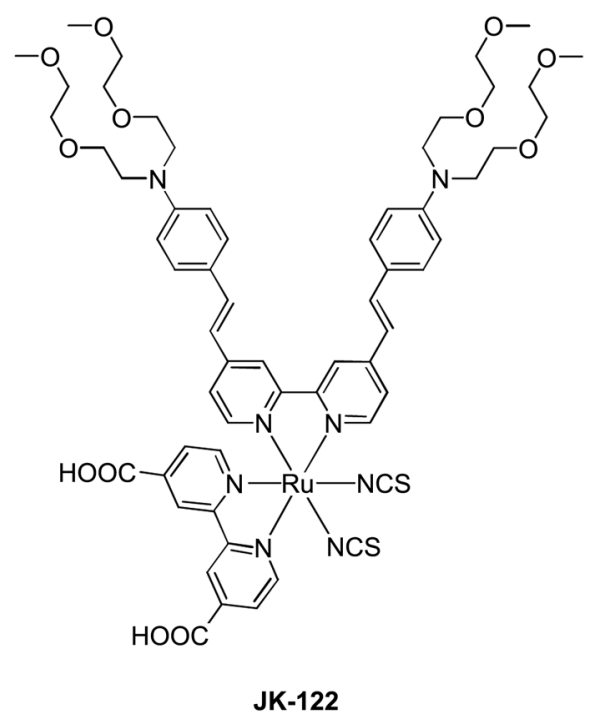

JK-122

Figure 1. Molecular structure of JK-121 and JK-122.

reference electrode, working electrode, and a platinum wire electrode. Redox potential of dyes on $\mathrm{TiO}_{2}$ was measured in $\mathrm{CH}_{3} \mathrm{CN}$ with $0.1 \mathrm{M}\left(\mathrm{n}-\mathrm{C}_{4} \mathrm{H}_{9}\right)_{4} \mathrm{~N}-\mathrm{PF}_{6}$ with a scan rate between $100 \mathrm{mVs}^{-1}$ (vs. NHE).

Nanosecond Laser Transient Absorption Measurements. Nanosecond transient absorption measurements were carried out by employing the technique of laser flash photolysis. In order to excite the sample solar cells, nanosecond pulse (3.5 ns fwhm) at $504 \mathrm{~nm}$ were generated by an H2-Raman shifter from the third harmonic generation (THG, $355 \mathrm{~nm}$ ) of Qswitched ND:YAG laser (Continuum, Surelite II). A Xenon lamp (ILC Technology, PS 300-1) was focused into the sample solution as the probe light for the transient absorption measurement. Temporal profiles were measured with a monochromator (DongWoo Optron, Monota 500i) equipped with a photomultiplier (Zolix Instruments Co., CR 131) and a digital oscilloscope (Tektronix, TDS-784D). Reported signals were averages of 3000 events.

Fabrication of DSSC. For the preparation of DSSC, a washed FTO (Pilkington, $8 \Omega \mathrm{sq}^{-1}$ ) glass plate was immerged in $40 \mathrm{mM} \mathrm{TiCl}_{4}$ aqueous solution as reported by the Grätzel group. The first $\mathrm{TiO}_{2}$ layer of $7 \mu \mathrm{m}$ thickness was prepared by screen printing with transparent mesoporous $\mathrm{TiO}_{2}$ paste (13 $\mathrm{nm}$ anatase, Solaronix), and the second opaque layer of 4 $\mu \mathrm{m}$ thickness (400 nm, CCIC) was coated for the purpose of light scattering. The $\mathrm{TiO}_{2}$ electrodes were immersed into the dyes (JK-121 and JK-122) solution $(0.3 \mathrm{mM}$ in acetonitrile: tert-butyl alcohol $=1: 1$ solution) and kept at room temperature for 18 hour. Counter electrodes were prepared by coating with a drop of $\mathrm{H}_{2} \mathrm{PtCl}_{6}$ soultion ( $2 \mathrm{mg} \mathrm{Pt}$ in $1 \mathrm{ml}$ ethanol) on a FTO plate. The electrolyte was then introduced into the cell, which was composed of 0.6 M 3-propyl-1,2-dimethyl imidazolium iodide (DMPImI), $0 \mathrm{M}$ (Electrolyte A) $/ 0.05 \mathrm{M}$ (Electrolyte B) $/ 0.25 \mathrm{M}$ (Electrolyte C)/0.3 M (Electrolyte D) lithium perchlorate, $0.1 \mathrm{M}$ iodine and $0.5 \mathrm{M} \mathrm{N}$-methylbenzimidazole (NMBI) in acetonitrile.

Characterization of DSSC. The cells were measured using $1000 \mathrm{~W}$ xenon light source, whose power of an AM 1.5 Oriel solar simulator was calibrated by using KG5 filtered $\mathrm{Si}$ reference solar cell. The incident photon-tocurrent conversion efficiency (IPCE) spectra for the cells were measured on an IPCE measuring system (PV Measurements).

Synthesis of $R u\left(4,4^{\prime}-b i s(4-(1,4,7,10-\right.$ tetraoxa-13-azacyclopentadecan-13-yl)styryl)-2,2'-bipyridine)(4,4'-dicarboxy2,2'-bipyridine)(NCS) 2 (JK-121). A mixture of L1 (0.18 g, $0.23 \mathrm{mmol})$ and $\left[\mathrm{Ru}(\mathrm{Cl})_{2}(p \text {-cymene })\right]_{2} \quad(0.069 \mathrm{~g}, 0.115$ $\mathrm{mmol}$ ) in DMF (40 ml) was heated to $80{ }^{\circ} \mathrm{C}$ for $4 \mathrm{~h}$ under nitrogen and then, 4,4'-dicarboxy-2,2'-bipyridine $(0.067 \mathrm{~g}$, $0.23 \mathrm{mmol}$ ) was added. The reaction mixture was heated to $140{ }^{\circ} \mathrm{C}$ for $4 \mathrm{~h}$ under nitrogen and in the dark. $\mathrm{NH}_{4} \mathrm{NCS}$ $(0.087 \mathrm{~g}, 1.15 \mathrm{mmol})$ was then added to the mixture and heating was continued for $4 \mathrm{~h}$. After cooling to room temperature, DMF was evaporated and water $(90 \mathrm{ml})$ was added. The resulting purple solid was filtered and washed with water. The crude complex was dissolved in basic methanol and further purified on a Sephadex LH 20 with methanol as an eluent. The main band was collected and precipitated with dilute acidic methanol to obtain pure JK121. ${ }^{1} \mathrm{H}$ NMR (300 MHz, DMSO- $\left.d_{6}\right) \delta 9.39$ (s, 2H), 9.1 (s, $2 \mathrm{H}), 8.95$ (s, 2H), $8.28(\mathrm{~s}, 2 \mathrm{H}), 7.55-6.55(\mathrm{~m}, 16 \mathrm{H}), 3.68-$ 3.55 (m, 40H). Anal. cal. for $\mathrm{C}_{60} \mathrm{H}_{66} \mathrm{~N}_{8} \mathrm{O}_{12} \mathrm{RuS}_{2}$ : C, 57.36; $\mathrm{H}$, 5.29. Found: C, 5702; H, 5.21.

Synthesis of $\mathrm{N}, \mathrm{N}$-Bis(2-(2-methoxyethoxy)ethyl)aniline (A). A solution of $N$-phenyldiethanolamine ( $3 \mathrm{~g}, 16.6 \mathrm{mmol})$ in acetonitrile $(40 \mathrm{ml})$ was added dropwise to a suspension of $\mathrm{NaH}$ (previously washed twice with hexane to remove the mineral oil, $1.6 \mathrm{~g}, 60 \%$ in $\mathrm{NaH}, 66.4 \mathrm{mmol}$ ) in acetonitrile $(30 \mathrm{ml})$ cooled with an ice-water bath, and then stirred at room temperature for $2 \mathrm{~h}$. A solution of 2-methoxyethyl methanesulfonate $(6.38 \mathrm{~g}, 41.3 \mathrm{mmol})$ in aceonitrile $(30 \mathrm{ml})$ was then added dropwise at $0{ }^{\circ} \mathrm{C}$. After refluxed overnight, acetonitrile was removed by evaporation, water was added, product was extracted with dichloromethane, dried over 
$\mathrm{MgSO}_{4}$, filtered and evaporated to dryness. Purification was carried out by silica gel column chromatography then, sticky yellow oil product A was obtained (3.9 g, 79.4\%). ${ }^{1} \mathrm{H}$ NMR $\left(300 \mathrm{MHz}, \mathrm{CDCl}_{3}\right) \delta 7.2\left(\mathrm{td}, 2 \mathrm{H}^{3} J=7.2\right), 6.72-6.64(\mathrm{~m}$, $3 \mathrm{H}), 3.63-3.51(\mathrm{~m}, 16 \mathrm{H}), 3.35(\mathrm{~s}, 9 \mathrm{H}) .{ }^{13} \mathrm{C}$ NMR $(75 \mathrm{MHz}$, $\left.\mathrm{CDCl}_{3}\right) \delta 147.2,128.7,115.4,111.1,71.4,69.7,68.1,58.1$, 50.4. Anal. cal. for $\mathrm{C}_{16} \mathrm{H}_{27} \mathrm{NO}_{4}$ : C, 64.62; $\mathrm{H}, 9.15$. Found: $\mathrm{C}$, $64.21 ; \mathrm{H}, 8.97$.

Synthesis of 4-(Bis(2-(2-methoxyethoxy)ethyl)amino) benzaldehyde (B). A solution of $\mathbf{A}(3 \mathrm{~g}, 10.09 \mathrm{mmol})$ and hexamethylene-tetramine $(1.84 \mathrm{~g}, 13.13 \mathrm{mmol})$ in trifluoroacetic acid $(5 \mathrm{ml})$ refluxed for 24 hours. The reaction mixture was cooled to room temperature. Then deionized water $/ \mathrm{H}_{2} \mathrm{SO}_{4}(1: 1 \mathrm{v} / \mathrm{v}$ solution $)(20 \mathrm{ml})$ was added into the reaction mixture solution, and then stirred at room temperature for $30 \mathrm{~min}$. The solution was neutralized by sodium carbonate at $\mathrm{pH} 7-8$. The product was extracted with dichloromethane and the organic phase was washed with deionized water two times then organic phase was dried over $\mathrm{MgSO}_{4}$, filtered and evaporated to dryness. Purification was carried out by flash silica gel column chromatography, obtaining sticky orange oil product B $(2.8 \mathrm{~g}, 85.3 \%)$. ${ }^{1} \mathrm{H}$ NMR $\left(300 \mathrm{MHz}, \mathrm{CDCl}_{3}\right) \delta 9.6(\mathrm{~s}, 1 \mathrm{H}), 7.6\left(\mathrm{~d}, 2 \mathrm{H}^{3} J=7.2\right)$, $6.67\left(\mathrm{~d}, 2 \mathrm{H}{ }^{3} \mathrm{~J}=9\right), 3.6-3.42(\mathrm{~m}, 16 \mathrm{H}), 3.26(\mathrm{~s}, 9 \mathrm{H}) .{ }^{13} \mathrm{C}$ NMR $\left(75 \mathrm{MHz}, \mathrm{CDCl}_{3}\right) \delta 189.9,152.5,131.9,125,110.9$, 71.7, 70.4, 68, 58.8, 50.8. Anal. cal. for $\mathrm{C}_{17} \mathrm{H}_{27} \mathrm{NO}_{5}$ : C, $62.75 ; \mathrm{H}, 8.36$. Found: C, 62.28; H, 8.28.

Synthesis of 4,4'-(1E,1'E)-2,2'-(2,2'-bipyridine-4,4'-diyl)bis(ethene-2,1-diyl)bis( $N, N$-bis(2-(2-methoxyethoxy)ethyl)aniline) (L2). Solid $t$-BuOK $(0.33 \mathrm{~g}, 2.94 \mathrm{mmol})$ was added to a solution of 4,4'-bis(diethylmethylphosphonate)-2,2'bipyridine $(0.36 \mathrm{~g}, 0.74 \mathrm{mmol})$ and $\mathbf{B}(0.6 \mathrm{~g}, 1.84 \mathrm{mmol})$ in dry tetrahydrofuran (THF, $20 \mathrm{~mL}$ ). The resulting mixture was stirred overnight at room temperature under nitrogen. The slurry was then filtered over Celite and the filter cake washed with dichloromethane. Product was extracted with dichloromethane, dried over $\mathrm{MgSO}_{4}$, filtered and evaporated. Purification was carried out by silica gel column chromatography then, sticky red oil product $\mathbf{L 1}$ was obtained $(0.52 \mathrm{~g}$, 70.3\%). ${ }^{1} \mathrm{H}$ NMR ( $\left.300 \mathrm{MHz}, \mathrm{CDCl}_{3}\right) \delta 8.63\left(\mathrm{~d}, 2 \mathrm{H}^{3} J=5.1\right.$ ), $8.48(\mathrm{~s}, 2 \mathrm{H}), 7.45\left(\mathrm{~d}, 2 \mathrm{H}^{3} J=5.2\right), 7.35-7.3(\mathrm{~m}, 4 \mathrm{H}), 6.93(\mathrm{~d}$, $\left.2 \mathrm{H}^{3} J=16.5\right), 6.74\left(\mathrm{~d}, 6 \mathrm{H}^{3} J=8.1\right), 3.66-3.53(\mathrm{~m}, 32 \mathrm{H})$, 3.38 (s, 12H). ${ }^{13} \mathrm{C}$ NMR $\left(75 \mathrm{MHz}, \mathrm{CDCl}_{3}\right) \delta 156.1,149.2$, 148.1, 147.4, 133.3, 128.7, 115.8, 111.6, 71.4, 69.9, 68.1, 58.3, 50.9. Anal. cal. for $\mathrm{C}_{46} \mathrm{H}_{62} \mathrm{~N}_{4} \mathrm{O}_{8}: \mathrm{C}, 69.15 ; \mathrm{H}, 7.82$. Found: C, 69.48; H, 7.92.

Synthesis of $R u\left(4,4^{\prime}-\left(1 E, 1^{\prime} E\right)-2,2^{\prime}-\left(2,2^{\prime}-\right.\right.$ bipyridine-4,4'diyl)bis(ethene-2,1-diyl)bis( $N, N$-bis(2-(2-methoxyethoxy)ethyl)aniline) $)\left(4,4\right.$ '-dicarboxy-2,2'-bipyridine)(NCS) ${ }_{2}$ (JK122). A mixture of $\mathbf{L 2}(0.64 \mathrm{~g}, 0.8 \mathrm{mmol})$ and $\left[\mathrm{Ru}(\mathrm{Cl})_{2}(p-\right.$ cymene $)]_{2}(0.24 \mathrm{~g}, 0.4 \mathrm{mmol})$ in DMF $(40 \mathrm{~mL})$ was heated to $80^{\circ} \mathrm{C}$ for $4 \mathrm{~h}$ under nitrogen and then, $4,4^{\prime}$-dicarboxy-2,2'bipyridine $(0.24 \mathrm{~g}, 0.8 \mathrm{mmol})$ was added. The reaction mixture was heated to $140{ }^{\circ} \mathrm{C}$ for $4 \mathrm{~h}$ under nitrogen and in the dark. $\mathrm{NH}_{4} \mathrm{NCS}(0.3 \mathrm{~g}, 4 \mathrm{mmol})$ was then added to the mixture and heating was continued for $4 \mathrm{~h}$. After cooling to room temperature, DMF was evaporated and water $(90 \mathrm{ml})$ was added. The resulting purple solid was filtered and washed with water. The crude complex was dissolved in basic methanol and further purified on a Sephadex LH 20 with methanol as an eluent. The main band was collected and precipitated with dilute acidic methanol to obtain pure JK-122. ${ }^{1} \mathrm{H}$ NMR (300 MHz, DMSO- $d_{6}$ ) $\delta 9.39$ (s, 2H), 9.1 $(\mathrm{s}, 2 \mathrm{H}), 8.95(\mathrm{~s}, 2 \mathrm{H}), 8.28(\mathrm{~s}, 2 \mathrm{H}), 7.55-6.55(\mathrm{~m}, 16 \mathrm{H}), 3.65-$ $3.53(\mathrm{~m}, 32 \mathrm{H}), 3.37(\mathrm{~s}, 12 \mathrm{H})$. Anal. cal. for $\mathrm{C}_{60} \mathrm{H}_{70} \mathrm{~N}_{8} \mathrm{O}_{12} \mathrm{RuS}_{2}$ : C, 57.17; H, 5.60. Found: C, 56.86; H, 5.48.

\section{Result and Discussion}

Syntheses and Characterization. The ruthenium sensitizers JK-121 and JK-122 were readily prepared by the stepwise synthetic protocol illustrated in Scheme 1. Compound $\mathbf{A}$ was synthesized using $\mathrm{O}$-alkylation reaction. The phenylamine derivative $\mathbf{A}$ was converted to its corresponding carbaldehyde $\mathbf{B}$ according to the Duff reaction. The aldehyde $\mathbf{B}$, upon reaction with 4,4'-bis(diethylmethyl-phosphonate)-2,2'-bipyridine in the presence of potassium tert-butoxide in THF, produced the ligand $\mathbf{L 2}$. The reaction of $\left[\mathrm{RuCl}_{2}(p \text {-cymene })\right]_{2}$ complex with $\mathbf{L 1}$ and $\mathbf{L 2}$, followed by the addition of 4,4'-dicarboxy2,2'-bipyridine resulted in the heteroleptic dichloro complexes. The chloro complexes react with a large excess of ammonium thiocyanate to afford the ruthenium sensitizers JK-121 and JK-122 (Scheme 1).

FT-IR Spectra. ATR-FTIR spectra of sensitizers JK-121 and JK-122 grafted on the surface of a $\mathrm{TiO}_{2}$ film are shown to be a powerful tool to reveal coordination behavior of lithium ion and structural information of JK-121 and JK122. Fig. 2 shows the typical ATR-FTIR of sensitizer JK121 adsorbed on $\mathrm{TiO}_{2}$ surfaces. The IR spectrum of JK-121 shows the bands at 1592 and $1381 \mathrm{~cm}^{-1}$, assigning as the asymmetric and symmetric modes of the carboxylate group. These indicate that the two carboxylic acids are involved the attachment of the sensitizer on the surface of $\mathrm{TiO}_{2}$ in an ester type. The coordinated NCS ligand exhibits a strong absorption at $2101 \mathrm{~cm}^{-1}$, typical of the N-coordinated thiocyanate group. The sensitizer exhibited a characteristic bipyridyl ring stretching mode at $1529 \mathrm{~cm}^{-1}$. The two absorption peaks at 2927 and $2849 \mathrm{~cm}^{-1}$ correspond to the asymmetric and symmetric stretching modes of the $\mathrm{CH}_{2}$ units of the ethylene oxide unit.

The coordination of sensitizer JK-121 with the lithium ion was investigated using ATR-FTIR spectroscopy. The JK-121 sensitizer adsorbed on the $\mathrm{TiO}_{2}$ film was dipped to a solution of $0.25 \mathrm{M}$ lithium iodide in acetonitrile. In the region of the $v$ (C-O) stretching mode at $1183 \mathrm{~cm}^{-1}$ in the $\mathbf{L 1}$ of JK-121, there is a significant shift to lower energy due to the complexation in $\mathbf{~} \mathbf{1}$ with lithium ion. Upon rinsing the $\mathrm{Li}^{+}-$ coordinated JK-121 dye with acetonitrile several times, the original peaks still remain intact. Therefore, the coordination of $\mathrm{Li}^{+}$in the 1,4,7,10-tetraoxa-13-azacyclopentadecane is shown to be strong compared with that of triethyleneoxide methyl ether (TEOME). Similar pattern was shown in the JK-122 (See S1) incorporated the bis(2-(2-methoxyethoxy) ethyl)-amine group as in the JK-121. An analysis of the spectrum in the Fig. 2 indicates that the original $v(\mathrm{C}-\mathrm{O})$ 


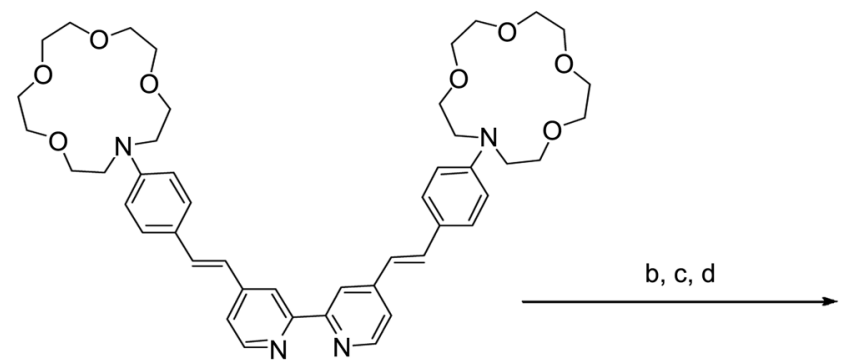

L 1
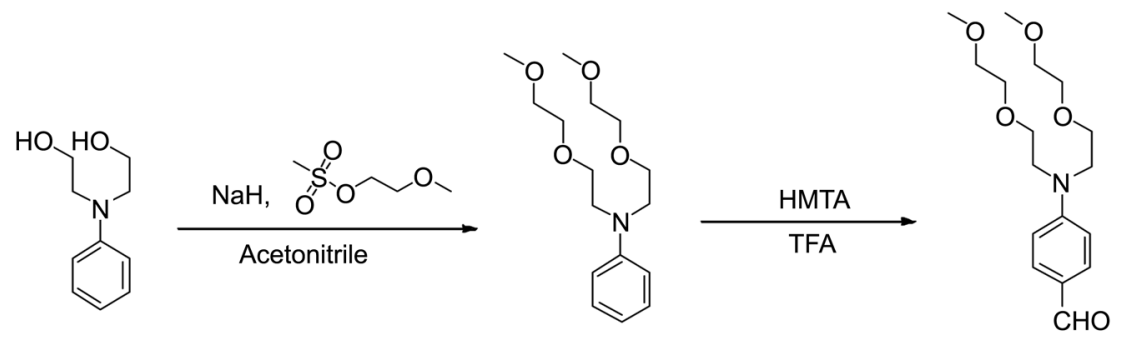

A

JK-122
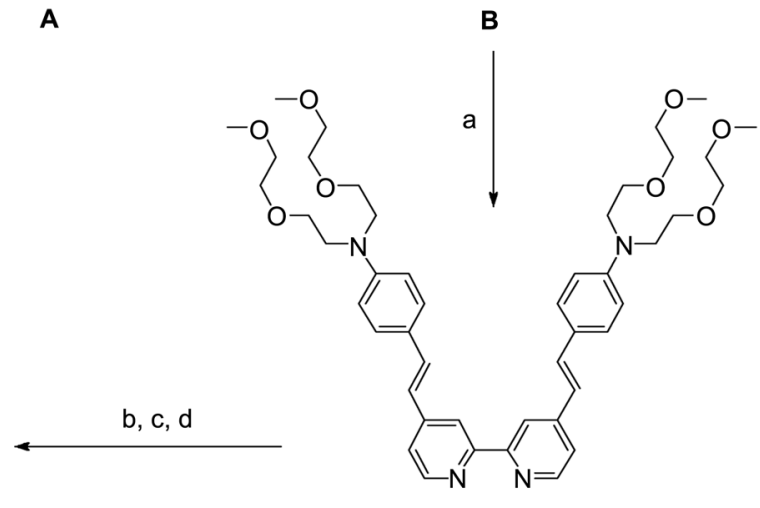

L 2

Scheme 1. Schematic diagram for the synthesis JK-121 and JK-122. Reagents and reaction condition : (a) 4,4'-bis(diethylmethylphosphonate)2,2'-bipyridine, $t$-BuOK, THF, rt; (b) $\left[\mathrm{RuCl}_{2}(p \text {-cymene) }]_{2}\right.$, DMF, $80{ }^{\circ} \mathrm{C}$; (c) $4,4^{\prime}$-dicarboxy-2,2'-bipyridine, DMF, $130{ }^{\circ} \mathrm{C}$; (d) $\mathrm{NH} 4 \mathrm{NCS}, \mathrm{DMF}$, $150^{\circ} \mathrm{C}$.

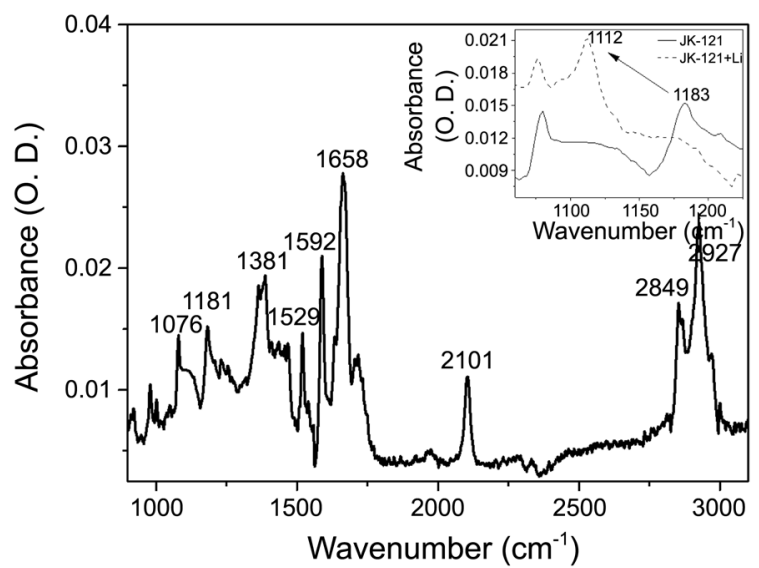

Figure 2. The ATR-FTIR spectrum of the JK-121 absorbed on a 6 $\mathrm{m}$ mesoporous $\mathrm{TiO}_{2}$. The inset shows the difference spectra after the addition of $0.25 \mathrm{M} \mathrm{Lil}$ in acetonitrile solution (after $5 \mathrm{~min}$ ).

peak is diminished by approximately $50 \%$ in the presence of the lithium ion. This result suggests that one $\mathrm{Li}^{+}$is coordinated to the JK-121 dye.

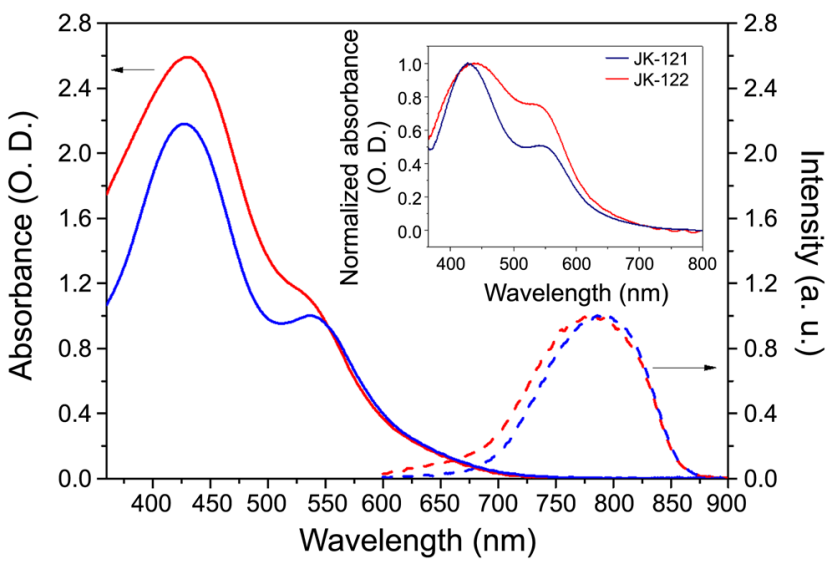

Figure 3. Absorption spectra of JK-121 (blue solid line) and JK122 (red solid line) and emission spectra of JK-121 (blue dash line) and JK-122 (red dash line) in $10^{-5} \mathrm{M}$ DMF solution. The insert shows absorption spectra of JK-121 (blue solid line) and JK-122 (red solid line) adsorbed on a nanocrystalline $\mathrm{TiO}_{2}$ film.

Optical Properties. The sensitizers JK-121 and JK-122 are weakly soluble in common organic solvents such as 
Table 1. Optical, redox, and DSSC performance parameters of dyes

\begin{tabular}{|c|c|c|c|c|c|c|c|c|}
\hline Dye & $\lambda_{\mathrm{abs}}{ }^{a} / \mathrm{nm}\left(\varepsilon / \mathrm{M}^{-1} \mathrm{~cm}^{-1}\right)$ & $E_{\mathrm{ox}}^{b} / \mathrm{V}$ & $E_{0-0}^{c} / \mathrm{V}$ & $E_{\mathrm{LUMO}}{ }^{d} / \mathrm{V}$ & $J_{s c}\left(\mathrm{mAcm}^{-2}\right)$ & $V_{o c}(\mathrm{~V})$ & F.F & $\eta(\%)$ \\
\hline JK-121 & $\begin{array}{l}426(28,420) \\
536(11,060)\end{array}$ & 1.05 & 1.82 & -0.77 & 13.08 & 0.69 & 0.77 & 6.95 \\
\hline JK-122 & $\begin{array}{l}429(42,290) \\
533(13,170)\end{array}$ & 1.03 & 1.88 & -0.85 & 10.46 & 0.67 & 0.76 & 5.32 \\
\hline Z907 & & & & & 10.21 & 0.65 & 0.76 & 5.04 \\
\hline
\end{tabular}

${ }^{a}$ Absorption spectra were measured in DMF. ${ }^{b}$ Redox potentials of dyes on $\mathrm{TiO}_{2}$ were measured in $\mathrm{CH}_{3} \mathrm{CN}$ with $0.1 \mathrm{M}\left(n-\mathrm{C}_{4} \mathrm{H}_{9}\right)_{4} \mathrm{NPF}_{6}$ with a scan rate of $100 \mathrm{mVs}^{-1}$ (vs. NHE) ${ }^{c} E_{0-0}$ was determined from intersection of absorption and emission spectra in ethanol. ${ }^{d} E_{\mathrm{Lumo}}$ was calculated by $E_{\mathrm{ox}}-E_{0-0}$.

acetonitrile and dichloromethane. Fig. 3 shows the UVvisible and emission spectra of the JK-121 and JK-122 sensitizers in $N, N$-dimethylformamide (DMF) solution, together with the UV-visible spectra of the corresponding sensitizers adsorbed on a $\mathrm{TiO}_{2}$ film. The absorption spectra of both sensitizers exhibit the characteristic metal-to-ligand charge transfer (MLCT) bands appearing at 426 and $536 \mathrm{~nm}$ in $\mathbf{J K}-\mathbf{1 2 1}$, and 429 and $533 \mathrm{~nm}$ in $\mathbf{J K}-\mathbf{1 2 2}$, which are about $15 \mathrm{~nm}$ red-shifted compared with those of Z907. The molar extinction coefficients of two bands are $28.4 \times 10^{3}$ and 11.0 $\times 10^{3} \mathrm{M}^{-1} \mathrm{~cm}^{-1}$ in $\mathbf{J K}-121$ and $42.3 \times 10^{3}$ and $13.1 \times 10^{3} \mathrm{M}^{-1}$ $\mathrm{cm}^{-1}$ in JK-122. The enhanced molar extinction coefficients and red shift compared with those of Z907 are attributable to the extension of the $\pi$-conjugation of both sensitizers.

The absorption spectra of JK-121 and JK-122 on $\mathrm{TiO}_{2}$ film are broadened due to the interaction of the anchoring group with the surface $\mathrm{TiO}_{2}$ (Insert in Fig. 2). We observed that the JK-121 and JK-122 sensitizers exhibited luminescence maxima at $791 \mathrm{~nm}$ and $780 \mathrm{~nm}$, respectively, when they are excited within their MLCT bands at $298 \mathrm{~K}$ in an air-equilibrated DMF solution.

Electrochemical Properties. The cyclic voltamogram of JK-121 and JK-122 on $\mathrm{TiO}_{2}$ films in $\mathrm{CH}_{3} \mathrm{CN}$ shows quasireversible couples at 1.05 and $1.03 \mathrm{~V}$ vs NHE, respectively (Table 1). Based on the intersection of absorption and emission spectra, the $E_{0-0}$ transition energy of JK-121 and JK-122 is calculated to be 1.82 and $1.88 \mathrm{eV}$. The excited state redox potentials $\left(\Phi^{\circ}\left(\mathrm{S}^{+} / \mathrm{S}^{*}\right)\right)$ of the sensitizers (JK-121, $-0.77 \mathrm{~V}$; JK-122, $-0.85 \mathrm{~V}$ vs NHE) is negative than the conduction band level of $\mathrm{TiO}_{2}$ at approximately $-0.5 \mathrm{~V}$ vs NHE, ensuring that there is an ample driving force for the electron injection into the conduction band of $\mathrm{TiO}_{2}{ }^{19}$.

Transient Absorbance Spectra. Electron injection from the photo-excited sensitizer is followed by the kinetic competition between recapture of the electrons trapped in the conduction band of the $\mathrm{TiO}_{2}$ film to the oxidized sensitizer $\left(\mathrm{S}^{+}\right)$or interception of the oxidized sensitizer by the redox couple. Since the kinetic competition between two charge-transfer pathways controls the photovoltaic performance, nanosecond laser experiments were performed to probe the kinetics of these two charge-transfer processes for JK-121 and JK-122 dyes. Transient absorbance signals obtained at probe wavelengths of $\lambda>620 \mathrm{~nm}$ are characteristic of the ligand-to-metal charge-transfer (LMCT) transition of the oxidized $\mathrm{Ru}$ (III) complex $\left(\mathrm{S}^{+}\right)$with thiocyanate ligands. In the absence of a redox mediator in acetonitrile, the decay
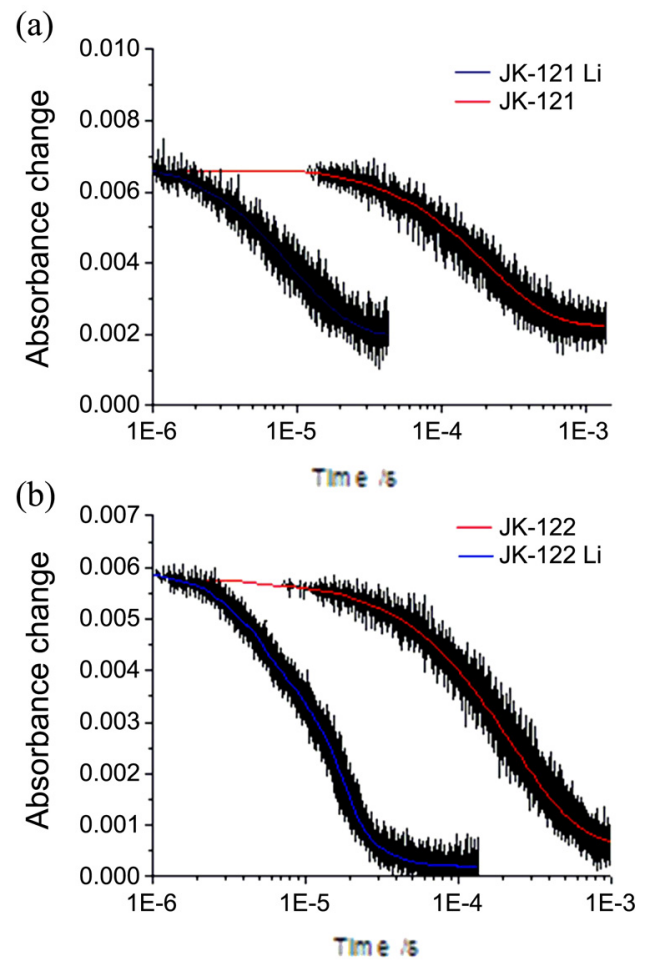

Figure 4. Transient absorbance decay kinetics of the oxidized state of (a) JK-121 and (b) JK-122 dye adsorbed on nanocrystalline $\mathrm{TiO}_{2}$ films in pure acetonitrile (red line), and in the presence of a iodide/triiodide redox couple electrolyte (blue line). Absorbance changes were measured at a probe wavelength of $680 \mathrm{~nm}$ upon 504 $\mathrm{nm}$ pulsed laser excitation. Signals as shown were obtain by averaging over 3000 .

of the absorption signal recorded at $680 \mathrm{~nm}$ demonstrates the dynamics of recombination of injected electrons with the oxidized Ru(III) complex. Fig. 4 shows that the kinetics of $\mathrm{S}^{+}$transient absorbance decay for the JK-121 dye has a halfreaction time $t_{1 / 2}=280 \mu \mathrm{s}$. The charge recombination kinetic for JK-121 dye is comparable to what has been reported for the standard N719 dye $\left(t_{1 / 2}=250 \mu \mathrm{s}\right)^{20}$ and longer than those of ion-coordinating ruthenium sensitizers $\left(t_{1 / 2} \sim 200 \mu \mathrm{s}\right)$. In the presence of the iodide/triiodide redox couple, the decay of the oxidized dye signal was significantly accelerated with the half-reaction time $t_{1 / 2}=4 \mu$ s. Therefore, the decay of the oxidized dye signal due to regeneration of the JK-121 dye is much faster than those $(10 \mu \mathrm{s})$ of dyes with the TEOME unit and comparable to that of $\mathbf{K 5 1}^{21}$ and $\mathbf{K 6 0}{ }^{16}$. Fast dye regeneration of the JK-121 sensitizer compared to the $\mathbf{K 5 1}$ 


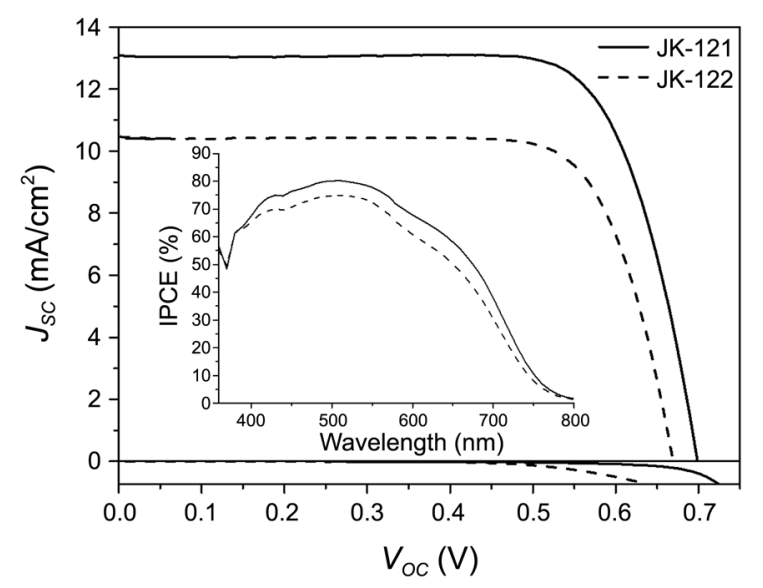

Figure 5. J-V curve and IPCE spectra of JK-121 (-) and JK-122 (...).

with TEOME unit and $\mathbf{Z 9 0 7}$ implies that more conduction band electron can transport to the electron collector along the $\mathrm{TiO}_{2}$ surface and thus increase the photocurrent density. The strong coordination of $\mathrm{Li}^{+}$in the 1,4,7,10-tetraoxa-13azacyclopentadecane of $\mathbf{J K - 1 2 1}$ is expected to increase the maximum approach between iodide and the ruthenium center or the thiocyanate ligand and hence increase the dye regeneration rate. A similar behavior was observed for the JK-122 dye.

Photovoltaic Performances. Fig. 5 shows a photocurrent density-voltage curve for the DSSCs based on the JK-121 and JK-122 under standard global AM 1.5 solar conditions. The detailed device parameters are listed in Table 1. The JK-121 and JK-122 sensitized cells gave the short-circuit photocurrent density $\left(J_{s c}\right)$ of 13.08 and $10.46 \mathrm{mAcm}^{-2}$, open circuit voltage $\left(V_{o c}\right)$ of 0.69 and $0.67 \mathrm{~V}$ and fill factor of 0.77 and 0.76 , corresponding to an overall conversion efficiency $\eta$ of 6.95 and $5.32 \%$ respectively. Using similar $\mathrm{TiO}_{2}$ electrode, electrolyte and measuring conditions the standard sensitizer $\mathbf{Z 9 0 7}$ sensitized cell gave a $J_{s c}$ value of 10.21 $\mathrm{mAcm}^{-2}$, a $V_{o c}$ of $0.65 \mathrm{~V}$ and an $f f$ of 0.76 , corresponding to a $\eta$ value of $5.04 \%$. When the photovoltaic performance of JK-121 and JK-122 is compared with that of Z907, which has a similar absorption spectrum, the efficiency of JK-121 and JK-122 is higher than that of $\mathbf{Z 9 0 7}$ due to an increase in the $J_{s c}$ and $V_{o c}$. We attribute the higher values of both parameters based on JK-121 and JK-122 to relate to the faster dye generation rate due to the strong coordination of $\mathrm{Li}^{+}$by the 1,4,7,10-tetraoza-13-azacylopentadecane unit or bis(2-(2-methoxyethoxy)ethyl)amine. The photocurrent action spectrum of JK-121 is shown in the insert of Fig. 5. The incident photon-to-current conversion efficiency (IPCE) of JK-121 exceeds 70\% in a broad spectral range 405-595 nm, reaching its maximum of $82 \%$ at $510 \mathrm{~nm}$. Integrating the IPCE curve over the solar spectrum of JK-121 results in a short circuit current of $12.96 \mathrm{mAcm}^{-2}$, which is in good agreement with the measured device photocurrent.

Effect of $\mathrm{Li}^{+}$on Photovoltaic Performance. The influence of various cations added to the electrolyte upon the photovoltaic performance of DSSCs has been well documented $^{22}$. Several studies have focused on the utilization of mobile lithium ions to control the interfacial charge transfer, such as tethering of the $\mathrm{Li}^{+}$ion to the surface, pyridine solubilized lithium ions in the organic HTM layer ${ }^{23}$, the addition of TEOME units to triarylamine-based molecular conductors, and ruthenium sensitizers tethering TEOME group. We investigated the effect of $\mathrm{Li}^{+}$on the photovoltaic parameters of the DSSCs with JK-121 and JK-122 bearing strong coordinating groups. Table 2 shows the influence of $\mathrm{Li}^{+}$concentration upon the short-circuit current and the open-circuit voltage using JK-121 sensitizer. With the addition of $\mathrm{Li}^{+}(50 \mathrm{mM})$ to the electrolyte $\mathbf{A}$, the photocurrent increases from 13.08 to $14.32 \mathrm{mAcm}^{-2}$ and the voltage decreases from 0.692 to $0.677 \mathrm{~V}$. The stepwise addition of $\mathrm{Li}^{+}$(250 and $300 \mathrm{mM}$ ) to the electrolyte $\mathbf{A}$ causes a slight increase in the photo-current density, with a small decrease in the open circuit voltage. This observation can be explained by a substantial red-shift and broad metal-to-ligand charge transfer (MLCT) peaks when the sensitizer on $\mathrm{TiO}_{2}$ film was coordinated with $\mathrm{Li}^{+}$ion (See Supporting Information Figure S4). Therefore, the device exhibits small changes in the power conversion efficiency $\eta$ upon an incremental addition of $\mathrm{Li}^{+}$. The observation can be rationalized in terms of the coordination of $\mathrm{Li}^{+}$to an ion-solvating group by preventing $\mathrm{Li}^{+}$from contacting the surface of $\mathrm{TiO}_{2}$. We also investigated the effect of $\mathrm{Li}^{+}$in the electrolyte with JK-121 and JK-122. When the lithium salt $\left(0.25 \mathrm{M} \mathrm{LiClO}_{4}\right)$ was added to the electrolyte, the $V_{o c}$ of JK-121 and JK-122 was dropped to $27 \mathrm{mV}$ and $18 \mathrm{mV}$, respectively. Under the same condition the $V_{o c}$ of $\mathbf{K 6 0}$ was dropped to $58 \mathrm{mV}^{16}$. The result shows that the sensitizers $\mathbf{J K}-121$ and $\mathbf{J K}-122$ are strongly coordinated to the $\mathrm{Li}^{+}$salt compared to $\mathbf{K 6 0}$. As the lithium ion has a significant effect upon controlling the interfacial electron transfer reactions in solid-state electrolyte, we extended our studies to such devices using 2,2',7,7'-tetrakis ( $N, N$-dimethoxyphenylamine)-9,9'-spirobifluorene (OMeTAD) as a hole conductor. We used lithium triflamide $\left(\mathrm{Li}\left[\mathrm{CF}_{3} \mathrm{SO}_{2}\right]_{2} \mathrm{~N}\right)^{24}$ as a lithium ion source. The JK-121 sensitized solid-state cell in the presence of $\mathrm{Li}^{+}(20 \mathrm{mM}$ in chlorobenzene) gave the short-circuit photocurrent density $\left(J_{s c}\right)$ of $9.54 \mathrm{mAcm}^{-2}$, open-circuit voltage $\left(V_{o c}\right)$ of $0.698 \mathrm{~V}$ and a fill factor of 0.39 , affording an overall conversion efficiency $\eta$ of $2.59 \%$. We find that the same device in the absence of $\mathrm{Li}^{+}$resulted in a poor performance $(\eta=1.85 \%)$. It is apparent that the addition of $\mathrm{Li}^{+}$in a hole conductor resulted in a $30 \%$ improvement in efficiency due to a strong coordination of $\mathrm{Li}^{+}$to an ion-complexing unit in $\mathbf{J K}-\mathbf{1 2 1}$. Such a $\mathrm{Li}^{+}$coordination results in a retardation of the interfacial recombination reaction due to electrostatic screening of the photo-injected electron from the hole transfer material (HTM) cation.

Impedance Spectra. The ac impedances of the cells were measured under illumination conditions (Fig. 6). The measurement showed three semicircles in the Nyquist diagram. Under the illumination $\left(100 \mathrm{mWcm}^{-2}\right.$, open-circuit voltage conditions), the radius of the intermediate frequency 
Table 2. Photovoltaic performance data of $\mathbf{J K}-\mathbf{1 2 1}$ containing different lithium cation concentration in the electrolyte

\begin{tabular}{ccccccc}
\hline Dye & Electrolyte & Conc. of $\mathrm{LiClO}_{4}$ & $J_{\text {sc }}\left(\mathrm{mAcm}^{-2}\right)$ & $V_{\text {oc }}(\mathrm{V})$ & F.F & $\eta(\%)$ \\
\hline \multirow{3}{*}{ JK-121 } & A & $0 \mathrm{M}$ & 13.08 & 0.692 & 0.77 & 6.95 \\
& B & $0.05 \mathrm{M}$ & 14.32 & 0.677 & 0.77 & 7.46 \\
& C & $0.25 \mathrm{M}$ & 14.52 & 0.665 & 0.75 & 7.24 \\
\hline
\end{tabular}

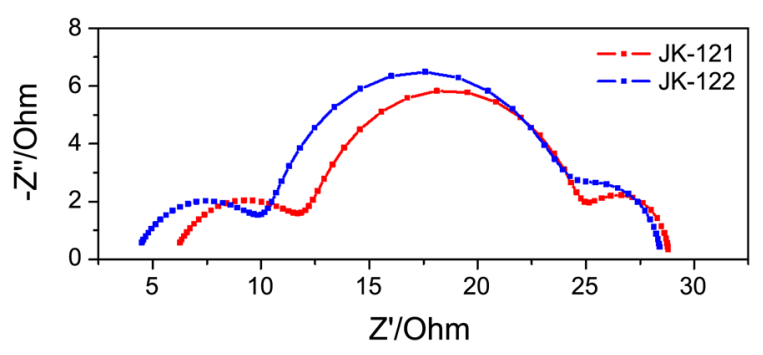

Figure 6. Electrochemical impedance spectra (nyquist plot) measured under the illumination $\left(100 \mathrm{mWcm}^{-2}\right)$ for the devices employing different dyes (Red : JK-121, Blue : JK-122).

semicircle in the Nyquist plot decrease in the order of JK$\mathbf{1 2 2}(12.96 \Omega)>\mathbf{J K}-121(11.65 \Omega)$, indicating the improved electron generation and transport. This result corresponds well to that of the short-circuit current shown in Table 1.

\section{Conclusion}

Two new ion coordinating ruthenium complexes $\left[\mathrm{Ru}(\mathrm{dcbpy})(\mathrm{L})(\mathrm{NCS})_{2}\right.$, where debpy is 4,4'-dicarboxylic acid-2,2'-bipyridine and $\mathbf{L}$ is 1,4,7,10-tetraoxa-13-azacyclopenta-decane or bis(2-(2-methoxyethoxy)ethyl)amine] were synthesized. The device based on the sensitizer JK-121 in the liquid electrolyte gave an overall conversion efficiency of $6.95 \%$. The lithium ion has a significant effect upon the photovoltaic performance particularly in solid-state electrolyte. The JK-121 sensitized solid-state cell in the presence of $\mathrm{Li}^{+}$ gave an overall conversion efficiency of $2.59 \%$, which showed a $30 \%$ improvement in efficiency compared with the device in the absence of $\mathrm{Li}^{+}$due to a retardation of the interfacial recombination. FTIR and nanosecond laser experiment studies proved the coordination effect of the JK121 and $\mathrm{Li}^{+}$.

Acknowledgments. We are grateful to the Korea University Research Program (2010).

\section{References}

1. (a) O'Regen, B.; Grätzel, M. Nature 1991, 353, 737. (b) Hagfeldt, A.; Grätzel, M. Chem. Rev. 1995, 95, 49. (c) Hagfeldt, A.; Grätzel, M. Acc. Chem. Res. 2000, 33, 269.

2. (a) Nazeeruddin, M. K.; De Angelis, F.; Fantacci, S.; Selloni, A.; Viscardi, G.; Liska, P.; Ito, S.; Takeru, B.; Grätzel, M. J. Am. Chem. Soc. 2005, 127, 16835. (b) Chiba, Y.; Islam, A.; Watanabe, Y.; Komiya, R.; Koide, N.; Han, L. Jpn. J. Appl. Phys. Part 2 2006, 45, L638. (c) Gao, F.; Wang, Y.; Shi, D.; Zhang, J.; Wang, M.; Jing, X.; Humphry-Baker, R.; Wang, P.; Zakeeruddin, S. M.;
Grätzel, M. J. Am. Chem. Soc. 2008, 130, 10720.

3. (a) Palomares, E.; Clifford, J. N.; Haque, S. A.; Lutz, T.; Durrant, J. R. J. Am. Chem. Soc. 2003, 125, 475. (b) Clifford, J. N.; Yahioglu, G; Milgrom, L.; R.; Durrant, J. R. Chem. Commun. 2002, 1260. (c) Palomares, E.; Clifford, J. N.; Haque, S. A.; Lutz, T.; Durrant, J. R. Chem. Commun. 2002, 1464.

4. (a) Brown, T. M.; Friend, R. H.; Millard, I. S.; Lacey, D. J.; Burroughes, J. H.; Cacialli, F. Appl. Phys. Lett. 2001, 79, 174. (b) Palomares, E.; Clifford, J. N.; Haque, S. A.; Lutz, T.; Durrant, J. R. J. Am. Chem. Soc. 2003, 125, 574. (c) Kruger, J.; Bach, V.; Grätzel, M. Adv. Mater. 2000, 12, 447.

5. Handa, S.; Haque, S. A.; Durrant, J. R. Adv. Funct. Mater. 2007, 17, 2878.

6. (a) Satoh, N.; Nakashima, T.; Yamamoto, K. J. Am. Chem. Soc. 2005, 127, 13030. (b) Nakashima, T.; Satoh, N.; Albrecht, K.; Yamamoto, K. Chem. Mater. 2008, 20, 2538.

7. (a) Jiang, K. -J.; Masaki, N.; Xia, J. -B.; Noda, S.; Yanagida, S. Chem. Commun. 2006, 2460. (b) Gao, F.; Wang, Y.; Zhang, J.; Shi, D.; Wang, M.; Humphry-Baker, R.; Wang, P.; Zakeeruddin, S. M.; Grätzel, M. Chem. Commun. 2008, 2635. (c) Chen, C. -Y.; Wu, S. -J.; Wu, C. -G.; Chen, J. -G.; Ho, K. -C. Angew. Chem. Int. Ed. 2006, 45, 5822. (d) Koumura, N.; Wang, Z. -S.; Mori, S.; Miyashita, M.; Suzuki, E.; Hara, K. J. Am. Chem. Soc. 2006, 128, 14256. (e) Choi, H.; Baik, C.; Kang, S. O.; Ko, J.; Kang, M. -S.; Nazeeruddin, M. K.; Grätzel, M. Angew. Chem. Int. Ed. 2008, 47, 327.

8. (a) Wang, P.; Zakeeruddin, S. M.; Humphry-Baker, R.; Grätzel, M. Chem. Mater. 2004, 16, 2694. (b) Wang, P.; Zakeeruddin, S. M.; Humphry-Baker, R.; Moser, J. E.; Grätzel, M. Adv. Mater. 2003, 15, 2101.

9. (a) Nakade, S.; Kambe, S.; Kitamura, T.; Wada, Y.; Yanagida, S. J. Phys. Chem. B 2001, 105, 9150. (b) Lindström, H.; Södergren, S.; Solbrand, A.; Rensmo, H.; Hjelm, J.; Hagfeldt, A.; Lindguist, S. -E. J. Phys. Chem. B 1997, 101, 7717.

10. Park, T.; Haque, S. A.; Potter, R. J.; Holmes, A. B.; Durrant, J. R. Chem. Commun. 2003, 2878.

11. Haque, S. A.; Park, T.; Xu, C.; Koops, S.; Schulte, N.; Potter, R. J.; Holmes, A. B.; Durrant, J. R. Adv. Funct. Mater. 2004, 14, 435.

12. Hirata, N.; Kroeze, J. E.; Park, T.; Jones, D.; Haque, S. A.; Holmes, A. B.; Durrant, J. R. Chem. Commun. 2006, 535.

13. Kroeze, J. E.; Hirata, N.; Schmidt-Mende, L.; Orizu, C.; Ogier, S. D.; Carr, K.; Grätzel, M.; Durrant, J. R. Adv. Funct. Mater. 2006, $16,1832$.

14. Snaith, H. J.; Zakeeruddin, S M.; Schmidt-Mende, L.; Klein, C.; Grätzel, M. Angew. Chem. Int. Ed. 2005, 44, 6413.

15. Kuang, D.; Klein, C.; Snaith, H. J.; Moser, J. -E.; Humphry-Baker, R.; Comte, P.; Zakeeruddin, S. M.; Grätzel, M. Nano Lett. 2006, 6, 769.

16. Kuang, D.; Klein, C.; Ito, S.; Moser, J. -E.; Humphry-Baker, R.; Zakeeruddin, S. M.; Grätzel, M. Adv. Funct. Mater. 2007, 17, 154.

17. Beer, P. D.; Kocian, O.; Mortimer, R. J.; Ridgway, C. J. Chem. Soc. Chem. Commun. 1991, 1460.

18. Ros-Lis, J. V.; Garcia, B.; Jiménez, D.; M-Manez, R.; Sancenón, F.; Soto, J.; Gonzalvo, F.; Valldecabres, M. C. J. Am. Chem. Soc. 2004, 126, 4064.

19. (a) Bond, A. M.; Deacon, G. B.; Howitt, J.; MacFarlane, D. R.; Spiccia, L.; Wolfbauer, G. J. Electrochem. Soc. 1999, 146, 648. (b) Wang, P.; Zakeeruddin, S. M.; Moser, J. -E.; Grätzel, M. J. Phys. 
Chem. B 2003, 107, 13280.

20. Pelet, S.; Moser, J. E.; Grätzel, M. J. Phys. Chem. B 2000, 104, 1791.

21. Kuang, D.; Klein, C.; Snaith, H. J.; Moser, J.-E.; Humphry-Baker, R.; Comte, P.; Zakeerudin, S. M.; Grätzel, M. Nano. Lett. 2006, 6, 769.
22. Zahan, A.; Meier, A.; Gregg, B. A. J. Phys. Chem. B 1997, 101, 7985.

23. Kruger, J.; Plass, R.; Cevey, L.; Piccirelli, M.; Grätzel, M.; Bach, U. Appl. Phys. Lett. 2001, 79, 2085.

24. Schmidt-Mende, L.; Zakkeruddin, S. M.; Grätzel, M. Appl. Phys. Lett. 2005, 86, 013504 